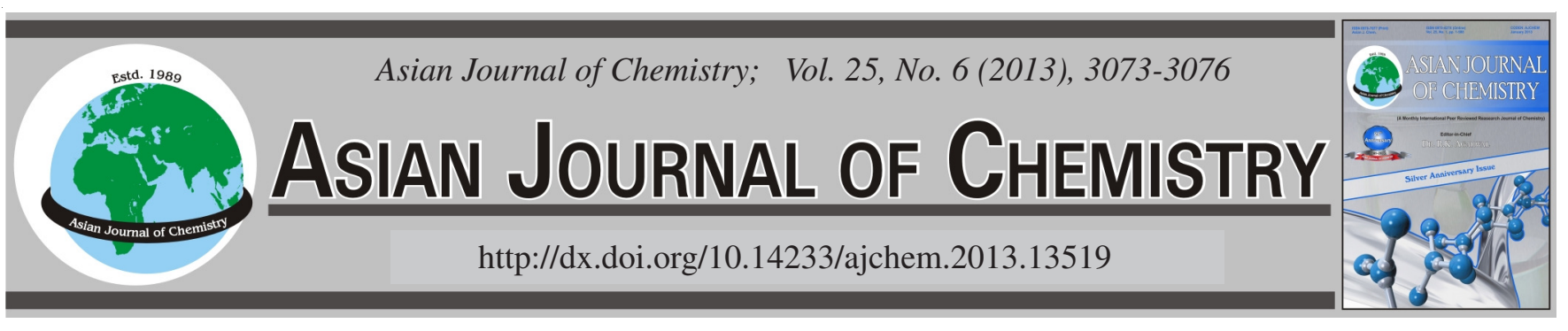

\title{
Comparative Study for Replacing Dry Cooling Tower Instead of Wet Cooling Tower in Oil Refineries
}

\section{Roozbeh Hoseinzadeh Hesas ${ }^{1}$, Mazyar Sharifzadeh Baei ${ }^{1, *}$, Amir Hossein Tarighaleslami ${ }^{2}$ and Soroush Younessi Sinaki ${ }^{3}$}

\author{
${ }^{1}$ Islamic Azad University, Science and Research, Ayatollah Amoli Branch, Amol, Iran \\ ${ }^{2}$ Chemical Engineering Faculty, Mahshahr Branch, Islamic Azad University, Mahshahr, Iran \\ ${ }^{3}$ Department of Environment and Energy, Science and Research Branch, Islamic Azad University, Tehran, Iran \\ *Corresponding author: Fax: +98 121 2517209; Tel: +98 9111145224; E-mail: mazyar.sharifzadeh@gmail.com
}

Key Words: Dry cooling tower, Wet cooling tower, Comparative study, Economic.

\section{INTRODUCTION}

Cooling towers are still widely used in industry and air conditioning to cool the circulating water ${ }^{1}$. The cooling tower is relatively inexpensive and reliable device and is used to remove heat from the water-cooled refrigeration, air conditioning, power plants and other industrial process control systems $^{2,3}$. Cooling tower can remove heat from a system or process without consuming excessive amounts of water.

The rate of consumption of water from the cooling tower is only about $5 \%$, once through the system, making it the most expensive system to operate with purchased water. The amount of heated water discharged by cooling tower in the form of blow down is very small ${ }^{4}$. The use of cooling towers to reject heat, cool buildings and reduce the temperature of water circulated through various heat rejection equipments have increased considerably ${ }^{5}$. Depending on the mode of heat transfer, cooling towers, respectively, are called wet towers; evaporative cooling when used dry tower, when the air blast cooling is used and the wet-dry type, which is the simultaneous performance of dry and wet towers.

The cooling effect of wet cooling towers, evaporative condenser is partially due to the quota, which circulates water gets evaporated and partly at the expense of sensible heat transfer. On the other hand, the cooling effect is achieved due to convective heat transfer and irradiative from any hot surface of the metal in the air stream moves along the surface and finally dissipates heat into the atmosphere ${ }^{6}$. Cooling towers are one of the most widely pieces of equipment used in refrigeration systems, which also consist of a network of heat exchangers in a closed circuit, which consume only water to compensate for inherent losses in the process. Thermal characteristics of the cooling tower is of vital importance in the process?

Air heat-diffusion technique is a useful technique in thermal power stations. It has the advantages of water conservation, environmental protection and maintenance of the equipment clean. It is important for energy development in the north China, where there are rich deposits of coal, but poor water. The Heller type dry-cooling tower and the steam turbine set are used together and a significant water resource saving efficiency is obtained. But it turns out that the cooling efficiency is strongly dependent on environmental conditions such as temperature, wind speed cross, etc. In the summer season and the wind, the cooling efficiency of the tower is clearly reduced and the electricity produced by power plant is reduced to a 
great extent due to the higher ambient temperatures or cross winds faster than $4 \mathrm{~m} / \mathrm{s}$. It is beneficial to analyze the reasons behind the inefficiency of the thermal performance of drycooling towers. Since the past 20 years, there have been two different methods, numerical simulation and the experimental method, to investigate the thermal performance of dry-cooling towers. Numerous measurements on a full-scale tower were carried out too ${ }^{8}$.

Bulb temperature is a limitation for cooling circulating water in cooling towers. There are two types of bulb temperature: 1-Wet bulb temperature; 2- Dry bulb temperature (outside temperature). It is not possible to cooling circulate water in wet cooling towers under wet bulb temperature and in dry cooling towers under dry bulb temperature. For creating preliminary theory to replacing dry cooling tower, first, the highest monthly mean air temperature charts of Tabriz vs. months of the year to be draw. Physical limitations restrict cooling towers operations with approach temperature less than $3^{\circ} \mathrm{C}^{9}$. According to eqn. 1 by considering approach temperature equal $3{ }^{\circ} \mathrm{C}$ output water temperature from cooling tower calculated. By consider approach temperature equal to $3{ }^{\circ} \mathrm{C}$ then moving the size of chart before $3{ }^{\circ} \mathrm{C}$ we achieve a minimum water temperature output from the tower in the average monthly temperatures reach. Based on data of Tabriz refinery output water temperature required by the cooling tower is $28^{\circ} \mathrm{C}$. Now if we draw a line under temperature $28^{\circ} \mathrm{C}$ months in parallel to the axis.

Approach temperature $=$ Output water temperature Dry bulb temperature

In this case in the days since that low place crosses the line and put the chart are alone dry cooling tower can be used. Number these days is about 245 days. Three types of water wastes occur in wet cooling towers:

1) Evaporation lost $\left(\mathrm{W}_{\mathrm{e}}\right)$ : Water flow rate lost by evaporation, $\left.\mathrm{m}^{3} / \mathrm{h} ; 2\right)$ Drift and wind age lost $\left(\mathrm{W}_{\mathrm{d}}\right)$ : Water flow rate lost by entrainment, $\left.\mathrm{m}^{3} / \mathrm{h} ; 3\right)$ Blow down $\left(\mathrm{W}_{\mathrm{b}}\right)$ : Deliberate discharge of a water of wet cooling tower due to increased concentration of solids in the water circulatory ${ }^{10}$.

The summation total of waste waters called 'Makeup water ${ }^{11}$.

$$
\text { Makeup Water }=\mathrm{W}_{\mathrm{e}}+\mathrm{W}_{\mathrm{d}}+\mathrm{W}_{\mathrm{b}}
$$

CWT (output cooled water temperature $)=28^{\circ} \mathrm{C}$; HWT (input hot water temperature $)=56{ }^{\circ} \mathrm{C}$; Circulate water volume $=$ $11500 \mathrm{~m}^{3} / \mathrm{h} ; \mathrm{N}$ (cycle of concentration) $=3$.

According to the data of the Tabriz oil refinery; current cooling tower makeup water volume is $762.5\left(\mathrm{~m}^{3} / \mathrm{h}\right)$, which is injected to the system in two parts:

1) Raw makeup water rate of approximately $11 \%$ of the total makeup water price $0.086 \mathrm{US} \$ / \mathrm{m}^{3} ; 2$ ) Treated makeup water rate of approximately $89 \%$ of the total makeup water price $0.154 \mathrm{US} \$ / \mathrm{m}^{3}$.

Thus the total cost of monthly makeup water of Tabriz oil Refinery is $80,400 \mathrm{US} \$ / \mathrm{month}^{12}$.

Economic principles in order to review the definition of an objective function for a Trade-off between construction cost, installation and operation dry cooling tower and reduce the cost of wet cooling tower make-up water is more.

Objective function $=($ makeup water cost $)-[($ dry cooling tower cost $)+($ pump cost $)+($ fan cost $)]$
Dry cooling tower design calculations: In the replacement study of dry cooling tower instead of wet cooling tower, the most important factor is determining the area needed for a certain amount of water in the dry cooling tower. By determining the required area and calculate the overall cost of the dry cooling tower in comparison with the makeup water level decreased due to compensatory hybridization can be economical in the project be evaluated and discussed.

To calculate the cost of dry cooling tower, following costs should be calculated:

1) Required area (A); 2) Axial fan motor shaft power (F.P.); 3) Dry cooling towers construction, installation and commissioning costs (I.C.).

To calculate heat capacity of dry cooling towers $\left(\mathrm{C}_{\mathrm{Pw}}, \mathrm{m}\right.$, $\mathrm{U}, \mathrm{T}_{1}, \mathrm{~T}_{2}, \mathrm{P}_{\mathrm{in}}, \mathrm{f}$ ), water physical particular in average temperature $\left(\mathrm{C}_{\mathrm{Pa}}, \mu, \mathrm{k}\right)$ and air information (dry bulb temperature and refineries elevation from sea level) are necessary.

Design information and assumptions: Average circulating water temperature $49^{\circ} \mathrm{C}$, environment air temperature (Dry Bubble) $23.3^{\circ} \mathrm{C}$, refineries altitude of main sea level is $1362 \mathrm{~m}$. forced draft dry cooling tower with two fan and fin pipe with $25.4 \mathrm{~mm}$ outer diameter, $15.9 \mathrm{~mm}$ blade height, BWG $=12,64 \mathrm{~mm}$ tube pitch, triangular pipe design bundle, 18.28 $\mathrm{m}$ pipe length, 4 row tube and 7 pass tube, carbon steel pipe material, extruded aluminum fin material ( 0.4 fin number $/ \mathrm{mm}$ ). The dry cooling towers needed surface area is expressed by equations 4 to $\left.6^{13}\right]$ :

$$
\begin{aligned}
\mathrm{Q} & =\mathrm{m} \cdot \mathrm{C}_{\mathrm{p}} \cdot \Delta \mathrm{T} \\
\mathrm{LMTD} & =\frac{\left(\mathrm{T}_{1}-\mathrm{t}_{2}\right)-\left(\mathrm{T}_{2}-\mathrm{t}_{1}\right)}{\ln \left[\frac{\left(\mathrm{T}_{1}-\mathrm{t}_{2}\right)}{\left(\mathrm{T}_{2}-\mathrm{t}_{1}\right)}\right]} \\
\mathrm{A} & =\frac{\mathrm{Q}}{\mathrm{U} \cdot \text { LMTD }}
\end{aligned}
$$

Calculation of $\mathrm{Fa}$ (input area by using APSM factor), unit wide (using chosen tube length), $\mathrm{N}_{\mathrm{t}}$ (number of tubes by using APM factor), $G_{t}$ (mass velocity of water inside the tube), $N_{R}$ (reynolds number), $\Delta \mathrm{P}_{\mathrm{t}}$ (total pressure drop in straight tubes by using water density) and $\mathrm{h}_{\mathrm{t}}$ (film coefficient based on inside tube surface) is expressed by eqns. 7 to $13^{3,14}$.

$$
\begin{gathered}
\mathrm{Fa}=\frac{\mathrm{A}}{\mathrm{ASPM}} \\
\text { Widht }=\frac{\mathrm{Fa}}{\mathrm{L}} \\
\mathrm{N}_{\mathrm{t}}=\frac{\mathrm{A}}{(\mathrm{APM})(\mathrm{L})} \\
\mathrm{G}_{\mathrm{t}}=\left(\frac{\left.\mathrm{W}_{\mathrm{t}} \cdot \mathrm{N}_{\mathrm{p}}\right)\left(\frac{106 \mathrm{~mm}^{2}}{\mathrm{~N}_{\mathrm{t}} \cdot \mathrm{A}_{\mathrm{t}}}\right)}{1 \mathrm{~m}^{2}}\right) \\
\mathrm{N}_{\mathrm{R}}=\frac{\mathrm{D}_{\mathrm{i}} \times \mathrm{G}_{\mathrm{t}}}{\mu} \\
\mathrm{P}_{\mathrm{t}}=\frac{\text { fYLN }_{\mathrm{p}}}{\phi}+\mathrm{BN} \mathrm{N}_{\mathrm{P}}(\text { for hydrocarbons } \\
\text { water steam and water } \mathrm{f}=1.0) \\
\mathrm{h}_{\mathrm{t}}=\frac{\mathrm{J} \cdot \mathrm{k}\left[\frac{\mathrm{Cp} \cdot \mu}{\mathrm{k}}\right]^{\frac{1}{2}} \cdot \phi}{\mathrm{D}_{\mathrm{i}}}
\end{gathered}
$$


Input air volume and mass velocity of air side calculated by eqns. 14 and 15 :

$$
\begin{gathered}
\mathrm{W}_{\mathrm{air}}=\frac{\mathrm{Q}}{\left(\mathrm{Cp}_{\mathrm{a}}\right)\left(\Delta \mathrm{t}_{\mathrm{a}}\right)} \\
\mathrm{G}_{\mathrm{a}}=\frac{\mathrm{W}_{\mathrm{a}}}{\mathrm{F}_{\mathrm{a}}}
\end{gathered}
$$

For fan calculations such as low area of fan (FAPF) and fan diameter eqns. 16 and 17 have been used:

$$
\begin{gathered}
\text { FAPF }=\frac{\left[0.4 \times \mathrm{F}_{\mathrm{a}}\right]}{\text { number of fans }} \\
\text { Fan diameter }=\left[\frac{4(\mathrm{FAPF})}{\pi}\right]
\end{gathered}
$$

$\Delta \mathrm{Pa}$ (static pressure drop by using $\mathrm{F}_{\mathrm{p}}$ and $\mathrm{D}_{\mathrm{R}}$ in average temperature) calculated by eqn. $18 .^{14}$

$$
\Delta \mathrm{P}_{\mathrm{a}}=\frac{\left(\mathrm{F}_{\mathrm{p}}\right)(\mathrm{N})}{\left(\mathrm{D}_{\mathrm{R}}\right)}
$$

For calculation real volume of air, $\mathrm{D}_{\mathrm{R}}$ in input air temperature to the fan should be used:

$$
\operatorname{ACMS}=\frac{\mathrm{W}_{\mathrm{a}}}{\left(\mathrm{D}_{\mathrm{R}}\right)}\left(1.203 \frac{\mathrm{kg}}{\mathrm{m}^{3}}\right)
$$

The calculated ACMS from equation 19 should divide to two, because we considered two fans for this dry cooling tower. For calculation approximate total pressure of fan, $D_{R}$ in input temperature to the fan should be considering.

$$
\mathrm{P}_{\mathrm{F}}=\Delta \mathrm{P}_{\mathrm{a}}+\mathrm{D}_{\mathrm{R}}\left(0.975 \frac{\mathrm{kg}}{\mathrm{m}^{3}}\right)\left(\frac{\text { ACMSperfan }}{\text { Fandiameter }^{2}}\right)^{2} \times\left(\frac{\frac{\mathrm{P}_{\mathrm{a}}}{\mathrm{kg}}}{\mathrm{m} \cdot \mathrm{s}^{2}}\right)
$$

Break horsepower for each fan calculated by eqn. ${ }^{21}$ :

$$
\text { Fan power }=\left[(\text { ACMS for each fan }) \times \frac{(\mathrm{PF})}{[\text { Fans yield }]}\right]
$$

\section{Economical calculations of dry cooling tower:}

Process economic science laws: The main purpose of each process is income creation, so knowing economic laws of process in designing is more important. Economic science in process designing includes three main laws: (Evaluation of design option, process optimization and process total utilization). Parts of equipments costs are function of four factors: (size, materials structure, design pressure and design temperature).

Construction, installation and commissioning costs of various equipments: For determining the equipment costs regarding to their capacity can use the following equation $\left.{ }^{15}\right]$ :

$$
\mathrm{C}_{\mathrm{E}}=\mathrm{C}_{\mathrm{B}}\left(\frac{\mathrm{Q}}{\mathrm{Q}_{\mathrm{B}}}\right)^{\mathrm{M}}
$$

For updating the annular costs of different years can use the following equation:

$$
\frac{\mathrm{C}_{1}}{\mathrm{C}_{2}}=\frac{\text { INDEX1 }}{\text { INDEX2 }}
$$

Materials used in the structure of equipment, operating pressure and temperature of a specific effect on the main equation will cost the correction coefficients related to each of these cases should be in order. Thus following formula will be used:

$$
C_{E}=C_{B}\left(\frac{Q}{Q_{B}}\right)^{M} f_{m} f_{p}
$$

The overall cost processes, services and workers can be multiplied by a factor in the cost of installation and equipment intended by the following formula is obtained the expression:

$$
\mathrm{C}_{\mathrm{F}}=\sum_{\mathrm{i}} \mathrm{f}_{\mathrm{i}} \mathrm{C}_{\mathrm{E}} \mathrm{i}
$$

Thus total cost of construction, installation and commissioning of equations is equal to:

$$
\begin{aligned}
& \mathrm{C}_{\mathrm{F}}=\sum_{\mathrm{i}}\left[\mathrm{f}_{\mathrm{m}} \mathrm{f}_{\mathrm{p}} \mathrm{f}_{\mathrm{t}}\left(1+\mathrm{f}_{\text {PIP }}\right)\right]_{\mathrm{i}} \mathrm{C}_{\mathrm{E}_{\mathrm{i}}}+\left(\mathrm{f}_{\mathrm{ER}}+\mathrm{f}_{\text {INST }}+\mathrm{f}_{\text {ELEC }}+\mathrm{f}_{\text {UTIL }}\right. \\
& \left.+\mathrm{f}_{\mathrm{OS}}+\mathrm{f}_{\text {BULD }}+\mathrm{f}_{\mathrm{SP}}+\mathrm{f}_{\text {DEC }}+\mathrm{f}_{\text {CON }}+\mathrm{fws}\right) \sum_{\mathrm{i}} \mathrm{C}_{\mathrm{E}, \mathrm{i}}
\end{aligned}
$$

Calculated costs from the formula, construction, installation and commissioning of equipment based on CCF if the cost as per dollar per year multiplied by the years and dividing this amount by 12 monthly cost of installing dry cooling tower.

Considering the volumetric flow rate of water pump inlet, pump flow from the vertical axis should use the following formula, which will cost only a function of pumping input water flow ${ }^{13}$.

$$
\mathrm{C}=0.02(\mathrm{gpm})^{0.78} \mathrm{k} \text { US\$, } 100<\mathrm{tpm}<13000
$$

According to the above formula, construction, installation and commissioning costs of pump is equal to: select pipes made from carbon steel, equal to the input pressure 1.2 bar and finding related information from tables. To calculate break kilowatt station using the following formula: ${ }^{12}$.

$$
\mathrm{bkw}=\frac{\mathrm{Q} . \Delta \mathrm{P}}{3600 \times \mathrm{e}}
$$

Calculating the real power pumps and electric power fan motor monthly electricity costs can be equal to power $\times 25.2$ US\$/month can be calculated. Cooling tower operates in all hours of day and night in rest of the year so cooling system operating time is equal to $720 \mathrm{~h} / \mathrm{month}$.

Monthly cost of construction, installation and commissioning of dry cooling tower: Calculated cost from equation is dry cooling tower's installed cost and if multiply it to CCF with unit of (1/year) we earn yearly and monthly $\cos ^{15}$.

$$
\mathrm{CCF}=\left[\frac{(i+1)^{\mathrm{n}} \times \mathrm{i}}{(\mathrm{i}+1)^{\mathrm{n}}-1}\right]
$$

where, $\mathrm{I}$ is industrial interest rate (17\%), $\mathrm{n}$ is useful operating life of system (15 years) and in result CCF is equal to 0.187822 .

Dry cooling tower monthly cost $=$

$$
\operatorname{CCF}\left(\frac{1}{\text { Year }}\right) \times \mathrm{C}_{\mathrm{F}}(\mathrm{Rls}) \times\left(\frac{\text { Year }}{12 \text { month }}\right)
$$


Study on replacing dry cooling tower instead of wet in $67 \%$ days of a year

General index of replacement method has been show in Fig. 1:

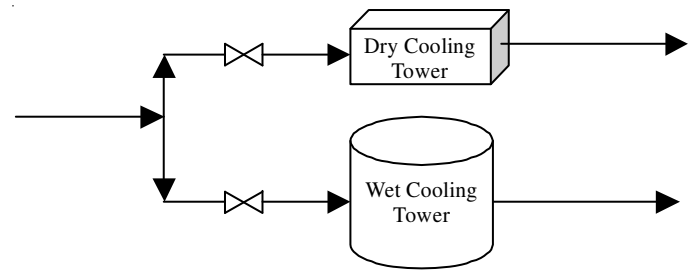

Fig. 1. Global aspect of replacing dry cooling instead of wet

In this study, according to the presented objective function there is an economical balance between decreasing makeup water cost of current wet cooling tower and increasing installation cost of dry cooling tower with attentive to explained methods in compare with decreasing makeup water cost. Replacement method for dry cooling tower instead of wet in 245 days of year is suitable and economical.

Calculation of replacing dry cooling water instead of wet in $\mathbf{2 4 5}$ days of year: In Table-1 operation parameters and estimate of dry cooling tower installed cost has been shown.

\begin{tabular}{lcr}
\multicolumn{3}{c}{ TABLE-1 } \\
\multicolumn{3}{c}{ DRY COOLING TOWER COST IN REPLACING } \\
\multicolumn{1}{c}{ METHOD IN TERMS OF US\$/MONTH } \\
\hline Temperature Range & {$\left[{ }^{\circ} \mathrm{C}\right]$} & 28 \\
\hline Heat capacity of dry cooling tower & {$[\mathrm{Mw}]$} & 373.34 \\
Required area for heat transfer & {$\left[\mathrm{m}^{2}\right]$} & 61,300 \\
Motor shaft power of fan in Temperature range & {$[\mathrm{kw}]$} & 6,360 \\
Construction, installation and commissioning cost & {$[\mathrm{US} \$]$} & $1,310,000$ \\
Dry cooling tower cost & {$[\mathrm{US} \$ /$} & $2,095,000$ \\
& month] \\
\hline
\end{tabular}

Manufacturing, installation and commissioning cost in replacing method: By using below relations, we can calculate related cost of pump with electrical power of $412.8 \mathrm{kw}$ and fan. $\mathrm{C}=0.02(50,600)^{0.78}, \mathrm{C}_{\mathrm{F}}=5.5 \mathrm{C}$, because in replacement method, dry cooling tower works just in 8 month of year so increase $33 \%$ (approximately 5 years) to the useful life of the dry cooling tower $\mathrm{CCF}=0.17769(1 / 8$ month $) \times \mathrm{C}_{\mathrm{F}}$.

In Table-2 total cost of replacing has been compared with saved makeup water cost.

TABLE-2

TOTAL REPLACING COST COMPARISON WITH SAVED MAKEUP WATER COST (US\$/8 MONTH)

\begin{tabular}{llr}
\hline Dry cooling tower cost & [US $\$ / 8$ month] & $2,095,000$ \\
\hline Fan electrical cost & [US $\$ / 8$ month] & $1,309,000$ \\
Pump electrical cost & {$[\mathrm{US} \$ / 8$ month] } & 86,800 \\
Pump cost & {$[\mathrm{US} \$ / 8$ month] } & 82,100 \\
Total replacing cost & {$[\mathrm{US} \$ / 8$ month] } & $3,573,000$ \\
Wet cooling tower water cost & {$[\mathrm{US} \$ / 8$ month] } & 643,200
\end{tabular}

\section{Conclusion}

By comparing the total replacement cost of dry cooling tower water by annual makeup cost in $67 \%$ of the days in a year in Tabriz refinery with considering Tabriz city climate, we found this method is not economically efficient, because total replacing cost for replacing dry cooling tower instead of wet cooling tower is 3,573,000 US\$/month. At the other hand, the saved makeup cost for this replacing according to the calculated methods is $643,200 \mathrm{US} \$ /$ month. However, the described problems related to the cooling system to review hybridization method in this system.

There are two suggestions method for current wet cooling tower hybridization, a: series method of current wet cooling tower with a dry cooling tower (in this method, firstly the rest of returned process hot water entered to dry cooling tower and cold water to determine temperature. Then this water entered second stage to the wet cooling tower to reach the required temperature and b: split methods (in this methods, some hot water entered to dry cooling tower and the rest of the water sent to wet cooling tower, the water which a few degree drop in temperature and then sent to dry cooling tower to reaches required temperature.

\section{REFERENCES}

1. X. Qi and Z. Liu, Energy Conv. Manage., 49, 570 (2008).

2. The Standard Handbook of Plant Engineering. McGraw-Hill, New York, edn. 2 (1995).

3. D.W. Green, R.H.P., Perry's Chemical Engineers' Handbook. McGrawHill, New York, edn. 6 (1984).

4. M.M.A. Sarker, G.J. Shim, H.S. Lee, C.G. Moon and J.I. Yoon, Appl. Thermal Eng., 29, 3328 (2009).

5. A.K.M. Mohiuddin, Int. J. Refrigerat., 19, 43 (1996).

6. M.M.A. Sarker, E. Kim, C.G. Moon and J.I. Yoon, Energy Buildings, 40, 1529 (2008).

7. C.F. Cortinovis, J.L. Paiva, T.W. Song and J.M. Pinto, Energy Conv. Manage., 50, 2200 (2009).

8. M.D. Su, G.F. Tang and S. Fu, J. Wind Eng. Ind. Aerodynam., 79, 289 (1999).

9. K.J. Bell and A.C. Mueller, Wolverine Tube Heat Tranfer Data Book. Electronic Distribution by Wolvrine Tube, Inc, Research and Development Team (2001),

10. G.Y. Jin, C.W., L. Lu, E.L. Lee and A.A. Chiang, Energy Convers. Manage., 48, 355 (2007).

11. C. Branan, Rules of Thumb for Chemical Engineering, Golf Publishing Company (1998).

12. GPSA, Gas Processes Supplier's Association Engineering Data Book, edn. 11 (1985).

13. M. Wallas, Chemical Processes Equipment. Golf Professional Publishing, edn. 2 (2005).

14. J.M. Douglas, Conceptual Design of Chemical Processes, McGraw Hills Publishing (1988).

15. R. Smith, Chemical Processes Design and Integration. John Wiley \& Sons Ltd., (2005). 